\title{
The Strategic Plan Evaluation of X Hospital in 2016-2021
}

\author{
Alif Khoiruddin Azizi * \\ *Correspondent Author : alif.kh.azizi@gmail.co.id \\ *PKU Muhammadiyah Yogyakarta Hospital, Yogyakarta, Indonesia
}

\section{N D E X I N G \\ Keywords: \\ Strategic plan; \\ Implementation; \\ Hospital; \\ Work program;}

Kata Kunci:

Rencana Strategi;

Pelaksanaan;

Rumah Sakit;

Program Kerja;

\begin{abstract}
A B S T R A C T
$\mathrm{X}$ Hospital has conducted the strategic plan and evaluated it, but there is inexpediency of work program and the budget sets in its implementation. Therefore, the goal of the strategic plan is not achieved and the unit performance is not maximal. Consequently, this study is aimed to analyze the process of the arrangement to the implementation of the Strategic Plan policy and the influencing factors. This research uses qualitative method. The primary data collection is conducted in-depth interview to 14 informants, while that of secondary data are obtained by reviewing the documents. The results show that the process of arranging and evaluating the strategic plan and the work program has not fully involved all the Directors and Managers concerned. Furthermore, the clarity and consistency of the Strategic Plan still lacks of the stage of implementation. The corporate performance-level parameters based on the balanced score card are not also descended to the Key Performance Indicator per directorate. However, the aspect of Human Resource understanding to the Strategic Plan has been fulfilled. Aspects of attitude and commitment both to the Executive Officers, Board of Directors and Managers are also very well.
\end{abstract}

Rumah Sakit X telah melakukan perencanaan strategis serta evaluasi terhadap rencana strategis tapi dalam implementasinya terdapat ketidaksesuaian dari program kerja dan anggaran yang ditetapkan sehingga tujuan rencana strategis tidak tercapai dan kinerja unit tidak maksimal. Penelitian ini bertujuan menganalisis proses penyusunan sampai dengan pelaksanaan kebijakan Rencana Strategis dan faktor faktor yang mempengaruhi. Penelitian ini menggunakan metode kualitatif. Pengumpulan data primer dilakukan dengan wawancara mendalam kepada 14 informan, data sekunder diperoleh dengan menelaah dokumen. Hasil penelitian menunjukkan proses penyusunan dan evaluasi rencana strategis dan program kerja belum sepenuhnya melibatkan semua Direksi dan Manajer terkait. Kejelasan dan konsistensi Rencana Strategis masih kurang pada tahap pelaksanaan. parameter kinerja tingkat corporate yang disusun berdasarkan balanced score card belum diturunkan pada Key Performance Indicator perdirektorat. Dari aspek pemahaman SDM terhadap Rencana Strategis sudah tercukupi. Aspek sikap dan komitmen baik pada Badan Pelaksana Harian, Direksi dan Manajer sangat baik.

(C) 2017 JMMR. All rights reserved

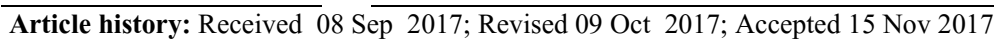

\section{INTRODUCTION}

Hospital is an institution whose activities always interact with the environment both external environment with wider community and the internal environment that is inside the hospital. The number of changes that occur in both circumstances always force the hospital to change management in order to survive. The hospital is called a unique organization ', because it blends between technology-intensive, labor-intensive and capital-intensive, and those require managerial expertise to put in it. A professional lifestyle that leads to a global culture and material-oriented forces the hospital managers to change due to what occurred. When the environment changes, the organization has a way or system to detect the change, to analyze the situation, to interpret it that becomes a stimulus to do action in response to the change. ${ }^{2}$

Hospital which originally is a social mission is getting more difficult to be implemented against increasingly high internal and external market pressures. As well as global market, the foreign capital investment in the health sector also increases, especially through the establishment of private hospital with foreign capital or through Foreign Investment (PMA) which will increase competition ${ }^{3}$.

In addition to market pressure, the increasing business competition is an external factor that also needs to be 
addressed. Only by maintaining a competitive advantage, organization can survive ${ }^{4}$. Thus, competitive advantage is highly dependent on the organizational innovative capacity. Competitive advantages based solely on products and processes alone will quickly and easily be imitated by competitors. Therefore, it is important for companies to have resources that produce comparative advantages ${ }^{5}$

Hospital that does not develop new products will be abandoned by consumers due to changing consumer tastes and needs, new technology and shorter product life cycles, and increased competition at home and abroad. To know what consumers want is an important thing to do in this competitive era.

Similarly, $X$ Hospital, which is originally established by the spirit of endeavor, should also bring about innovations in the product development because the contribution of humanitarian fund which is originally as a source of funding has decreased, and the hospital must change towards the middle to upper market segment, in order to cross subsidy. This is due to high operational costs, while assistance from charity funds has been sharply reduced. ${ }^{6}$

Various changes and issues both developing outside the environment and that occurred internally within the organization X Hospital have occurred such as patient safety, limited access to health services in certain communities, the development of science and technology, the burden of disease as a consequence of costs, namely as the accumulation of medical costs, economical, and psychosocial on a disease condition ${ }^{7}$ until widening of information boundaries that impact toward the increasingly critical customer to health services and to change in government regulations. Also, the changes occurring internally within Hospital are reflected from changing management systems, implementation of quality management standards and service development demands. Thus,these must be adapted rapidly through five-years development strategies and programs. The changes both internally and externally need to be adapted but they should not abandon basic rules as mandated mission from organization charity and efforts.

The purpose of this research is to know whether $\mathrm{X}$ Hospital has conducted the strategic planning steps as strategic decision and making process to improve strategic decision as stated by ${ }^{8}$ and ${ }^{9}$. The steps are stage I Analysis of External and Internal Environment, stage II Establishment organizational goals (vision, mission), stage III Formulation Strategy, stage IV implementation strategy, stage $\mathrm{V}$ control and evaluation strategy.

\section{METHOD RESEARCH}

This research uses a qualitative approach, which describes the object and subject of research through the process of analysis in the strategic plan X Hospital, ${ }^{10}$. The subjects of the study are the chairman of the Executive Officers and the Board of Directors up to the level of managers in X Hospital. The data on this research are primary data through in-depth interview and secondary data through document review.

After data collection is by looking at the document plan strategy, work program and budget of the hospital, then the data are analyzed using content analysis method, that is data collection, data reduction, and verification.

\section{RESULTS AND DISCUSSION}

\section{Result}

The provided services by $\mathrm{X}$ Hospital covers management aspects, services according to hospital classification as well as hospital facilities and medical equipment. In general, the health services provided are preventive, promotive, curative and rehabilitative by putting pressure on the curative and rehabilitative aspects with not leaving its role in the promotion and prevention of disease. Based on the role and nature of services and various aspects of hospital activities and services, $\mathrm{X}$ Hospital divides its service activities into two, that is intrahospital activities (indoor) in the form of individual services with individual and community approach. Activities in the form of curative and rehabilitative services are general and specialist medical services, nursing services, pharmaceutical services and other medical support services. In addition, extra hospital service (outdoor) is public health efforts that are promotive and preventive. The form of activities in the form of community service, health promotion and other activities based on community.

The types of services provided by X Hospital are Emergency Case Service, 24 Resuscitation Services, Outpatient Clinic General Surgery, Urology Clinic, Orthopedic Clinic, Neurosurgical Clinic, Surgical Clinic, Disease Clinic, Obstetrics and Gynecology Clinic, Clinic for Child Disease, Neurology Clinic, Ear Disease Clinic, Nose and Throat, Skin and Genital Disease Clinic, Heart Disease Clinic, Lung Disease Clinic, Eye Disease Clinic, Mental Health Clinic, Medical Rehabilitation Clinic, General Dental Clinic, Oral Surgery Clinic, Dental Conservation Clinic, Orthodontic Clinic, Periodontics Clinic, Dental Clinic, HIV/AIDS VCT Clinic, 
Hemodialysis Service, Inpatient Service including Intensive Care (ICU / ICCU and IMC) and Operating Room Services. It is also equipped with medical support facilities such as Laboratory Clinic, Rehabilitation Medical Clinic, Radiology, Nutrition, CSSD, and service of corpse proof.

\section{DISCUSSION}

X Hospital establishes Strategic Plan in 2016 - 2021 through Decree number: 210 / B-II / BPH-I / VII / 2015 that contains history and brief description of the hospital, Health Market Profile, Service Performance data, Financial Resources, Human Resources, SWOT, hospital Strategy, Corporate Performance Indicator and Work Program Development Stage.

\section{The Stage of Strategic Plan:}

Phase I Vision and Mission Evaluation

Vision Evaluation for the period of 2009- 2014 which is originally "To be a reliable Islamic referral hospital with quality service and Islamic health education, safe, professional, fast, comfortable and quality" becomes a vision of the period 2016-2021 "To be a X hospital a reliable referral with quality Islamic service, quality and affordable." From the evaluation concluded, the Vision period of 2009-2014 has not mentioned "X Hospital", while Vision Period 2016-2021 seeks to show its existence as the ownership of $\mathrm{X}$ hospital organization. Then, the efforts to be a trusted referral hospital re-listed in the vision of 20162021. This shows the commitment of X Hospital to remain to be the Referral Hospital and to maintain as a type B hospital. Furthermore, the phrase "safe, professional, fast, comfortable and good quality" is omitted and changed with the word "Islamic", because Islam already includes professional services, fast service, comfortable and quality. Moreover, the vision of the period 2016 - 2021 does not include Education, because the classification X Hospital is currently class B Non Education.

With the evaluated vision, the mission of $\mathrm{X}$ hospital changes where in the period 2009 - 2014 "Achieve optimal health status for all levels of society through approach to maintenance, to prevention, to treatment, health recovery as a whole in accordance with regulations/statutory provisions, quality for health personnel through training and education facilities held professionally and according to the guidance of Islamic teachings, Realizing the $d a^{\prime}$ wah of Islam, amar ma'ruf nahi munkar through health service with always keeping the rope of silaturrahim, as part of da'wah as exchange to 2016-2021 To provide full health services for all levels of society in accordance with laws and regulations, Organizing efforts are to improve the quality of human resources through education and training professionally in accordance with Islamic teachings, Implementing Islamic proselytizing, amar ma'ruf nahi munkar through health care, caring for the dhuafa'."

\section{Phase II Identifying Internal and External Factors and Internal Factors: Service Facilities, Financial Resources, Human Resources (SDI)}

External factors: Population and Economy data, data of population percentage in Yogyakarta Special Region (DIY), Data of percentage of poor DIY population, Proportion of DIY population expenditure, Population expenditure data by non-food type, percentage data Growth of various economic sectors, Health data Population and Health Services. $^{11,12}$

\section{Phase III SWOT Factor Strategy Identification ${ }^{13} ;^{14}$}

The analysis has not been done, hence it has not been able to describe the position of quadrant in SWOT table yet. $^{15}$

\section{Phase IV Establishing Corporate Performance Indicator $^{16}$}

This is a parameter to assess the achievement and success of an organization based on a balanced score card, but it has not been reduced to a strategic map and key performance unit yet.

\section{Phase V Establishing the Development Stage}

This phase is divided into 2 (two) periods, namely period I of 2016 - 2019 and period II 2020 - 2021.

Furthermore, the researchers search the document of Work Program and Budget 2016 to analyze the harmony between the work program and budget as the evaluation of the implementation of strategic plan with the results of mainly work program not budgeted.it is concluded that the managers' lack of conformity to the Strategic Plan is very high.

Further, the researcher conducts in-depth interview to find out details on the Evaluation Process and the implementation of the interview are conducted to the Chief Executive Officer as the owner of the Hospital, the Directors and Managers in each section. Interview results 
are as follows:

1) The Importance of the Strategic Plan for the Hospital, the Chief Executive Officer, the Board of Directors and the Manager stated that the Strategic Plan is very important for the journey of a hospital. The Strategic Plan is the management process in creating and maintaining the suitability between organizational goals with the resources This possession is used to capture the ever-evolving opportunities ${ }^{17}$. Strategic planning also examines how to select objective outcomes, organizational objectives and strategic action plans to disseminate and change if circumstances change, as well as how program progress is established. As stated by the Chairman of the foundation "that the strategic plan is very important because it contains the hospital strategy for 5 years, but in its journey needs to be evaluated because to adjust the current condition."

2) Involvement in drafting the Strategic Plan, Chief of the Executive Officers declared to be involved in the evaluation of the Strategic Plan, while not all Directors declared to be involved, and most of the managers said they were not involved. It is necessary policy to provide rewards based on compliance in the implementation of strategic decisions that have been formulated and the development of persuasive techniques to ensure attendance during the evaluation and implementation process as well as to increase the intensity of involvement ${ }^{18}$. Without the involvement of the stakeholders, it is impossible that the strategy will be implemented ${ }^{19}$. Intangible assets will determine success in the implementation of the Strategic Plan. Intangible assets consist of Human Capital (skills, talents, and knowledge), Information Capital (Databases, network, information systems, and technological infrastructures), and Organization Capital (Cultural, Leadership, employee alignment, team work, and knowledge management). The harmony of the intangible assets will determine the organization's readiness to implement its strategies.

3) Knowledge and understanding of the strategic plan, the head of Executive Officers, the Board of Directors and all levels of managers have already acquired knowledge about the Strategic Plan, but on average that is obtained through out-of-hospital activities. Specifically, training or learning has never been within the hospital. It needs to be a concern for management, thus, that all structural ranks are provided with understanding of the strategic plan. As stated that intangible assets are very important, therefore to make human capital function more effectively, efficiently, and productively, the same perception in knowledge, skill and attitude related to hospital strategic management system is needed. It consists of strategic environmental analysis, strategic planning, implementation, evaluation and its control ${ }^{8}$

As an interview with the Medical Director "I often get knowledge about the strategic plan in the discussion and workshop, so I understand about the strategic plan."

4) Evaluation of the Strategic Plan implementation. From the interviews results, it is found that the strategic plan has not been evaluated in terms of the harmony of the work program with the implementation. Besides, the manager has not been evaluated in compliance with the strategic plan in which the strategic plan has not been fully used as a guideline for activities, as well as the hospital administration requirement in operational and accreditation permits. Meanwhile, according to Wheelen and Hunger ${ }^{8}$, in the strategic decisionmaking process stage, the evaluation of strategic implementation is required through feedback system and the control of activities to ensure the smallest deviation from planning. As an interview with the Director of Medical Support "That the strategic plan has not been evaluated, so there are some activities that are not in accordance with the Strategic Plan, should the strategic plan be evaluated every year even to be revised."

\section{CONCLUSION}

The conclusions can be drawn based on the research results of intention and purpose of research as follows. In the process of preparation and evaluation of strategic plan, $\mathrm{X}$ Hospital has done several stages that are appropriate to the rules. Identification of external and internal factors has not been analyzed. SWOT strategy factor has not been analyzed so that it cannot be determined in what quadrant the position of X Hospital is currently located. Corporate Performance Indicator, the form of parameters to assess the achievement and success of the organization based on the balanced score card, is not down to the strategic map and key unit performance so that strategic goals and targets to be achieved by the unit are not found. The implementation of the strategic plan is not in line with the expectations from the intentions of the strategic plan. Many of implementation between the work program and the budget that are not 
aligned. This is because there is no evaluation and the achievement assessment of the strategic plan in the middle of the strategic plan implementation.

Chief of Executive Officers, Directors and Managers committed that strategic plans should be served as guidelines for operational activities of service because their understanding of the Strategic Plan has been sufficient.

\section{Suggestion}

1. X Hospital is expected to:

a. Conduct SWOT Analysis to know in what coordinate the X Hospital position is currently inside.

b. Corporate Performance Indicator is descended to be Key Performance Indicator per Directorate and all working units within X Hospital.

c. The annual plan program of hospital is arranged in the form of a Budgetary Business Plan in accordance with the Strategic Plan ${ }^{20}$.

d. Evaluate and assess the success of the strategic plan in the middle of the implementation so that the harmony between the strategic plan and implementation is achieved ${ }^{21}$.

2. The next researcher

For other researchers who want to research on the Strategic Plan, they can take other materials and be applied in the different places and add different variables.

\section{REFERENCE}

1. Saad Andaleeb S. Determinants of customer satisfaction with hospitals: a managerial model. Int J Health Care Qual Assur [Internet]. 1998 Nov 11 [cited 2017 Sep 5];11(6):181-7. Available from: http://www.emeraldinsight.com/doi/10.1108/0952686 9810231541

2. Widyastuti HC. Hubungan antara Budaya Organisasi Dengan Komitmen Organisasi Pada Perawat Rumah Sakit Panti Wilasa Citarum Semarang. undip.ac.id. 2003;0.

3. Pauzi A, Budiana DN. Faktor-Faktor yang Mempengaruhi Secara Langsung Maupun tidak langsung Ketimpangan Distribusi Pendapatan Provinsi Bali. E-JURNAL Ekon PEMBANGUNANA Univ UDAYANA VOL5, NO 6 Juni 2016. 2013;668-91.

4. Prasetya GLH, Rahardja E, Hidayati R, Produk I, Stratejik A, Lingkungan $\mathrm{P}$, et al. Membangun Keunggulan Kompetitif Melalui Aliansi Stratejik Untuk Meningkatkan Kinerja Perusahaan ( Studi Kasus Pada Pt . Pos Indonesia Wilayah Vi Jateng Dan
Diy ). 2007;4:1-19.

5. Ristrini. The Paradigm Change of Hospital Services and Strategic Policy Recommendation for Leaders. JMPK Vol 08/No01/Maret/2005. 2005;8(1):3-9.

6. Trisnantoro L. Memahami penggunaan ilmu ekonomi dalam manajemen rumah sakit. 2004;15.

7. Aikins A, Charles A, Addo J, Coast E, Grant L, Huang $\mathrm{K}-\mathrm{Y}$, et al. Chronic Non-Communicable Diseases in Low and Middle Income Countries. 2015.

8. Wheelen TL, Hunger JD. Strategic management and business policy [Internet]. Policy. 2012. 911 p. Available

from: http://books.google.com/books?id=J8YGhhK5keUC\& pgis $=1$

9. Fred R. David Francis Marion University Florence SCFRDSPC. Strategic management [Internet]. 2004. 1-35 p. Available from: http:/orca.cf.ac.uk/39359/

10. Moleong L. Metodologi penelitian. Kualitalif Sasial [Internet]. 2006;31-44. Available from: http://lib.uinmalang.ac.id/thesis/chapter_iii/07130097-hendrakurniawan.pdf

11. Dedi Septiadi Gunawan, Taher Alhabsji KR. Analisis Lingkungan Eksternal dan Internal dalam Menyusun Strategi Perusahaan. J Fak Ilmu Adm Univ Brawijaya Malang. 2017;22-33.

12. Yulianti D. Analisis Lingkungan Internal dan Eksternal dalam Pencapaian Tujuan Perusahaan (Studi Kasus di PT. Perkebunan Nusantara VII Lampung). 2014;16(2):103-14.

13. Ommani AR. Strengths, weaknesses, opportunities and threats (SWOT) analysis for farming system businesses management: Case of wheat farmers of Shadervan District, Shoushtar Township, Iran. African J Bus Manag [Internet]. 2010;5(22):9448-54. Available from: http://www.academicjournals.org/AJBM\%5Cnhttp:// www.academicjournals.org/journal/AJBM/articlefull-text-pdf/21F95E420498

14. Harrison JP. Strategic Planning and SWOT analysis. Essentials Strateg Plan Healthc [Internet]. 2010;1(12):91-108. Available from: http://www.ache.org/pdf/secure/gifts/Harrison_Chapt er5.pdf

15. FME. SWOT Analysis: Strategy Skills [Internet]. Free-Managment-Ebooks. 2013. 1-31 p. Available from: http://www.free-managementebooks.com/dldebk-pdf/fme-swot-analysis.pdf

16. Baroudi R. Key performance indicators: Winning tips and common challenges. EY Perform J. 
2014;6(2):36-43.

17. Nurhapna, Haksama S. Pengaruh Perencanaan Strategis Terhadap Kinerja Di Rumah Sakit. 2014;2(2):91-100.

18. Purba;, Rani Selvia dan Fitrotun Niswah,S.AP MA. Implementasi Strategi Ektstensifikasi Dalam Mencapai Target Penerimaan Pajak Pada Kantor Pelayanan Pajak (KPP) Pratama Surabaya Wonocolo. Ilmu Adm Negara,FISH, UNESA. 2016;1-12.

19. Kaplan RS, Norton DP. The strategy map: guide to aligning intangible assets. Strateg Leadersh [Internet]. 2004 Oct 13 [cited 2017 Nov 21];32(5):10-7. Available from: http://www.emeraldinsight.com/doi/10.1108/108785 70410699825

20. Husain FW, Hasjmy MA, Utama H, Suharjono. Pedoman Penyusunan Rencana Bisnis dan Anggaran (RBA) Badan Layanan Umum Rumah Sakit. 2009;

21. Kurniawan K. Analisis Implementasi Rencana Strategis di Unit Rawat Inap Rumah Sakit Keluarga Sehat Rumah. Univ Diponegoro Fak Kesehat Masy Progr Magister Ilmu Kesehat Masy Konsentrasi Adm Rumah Sakit. 2013; 